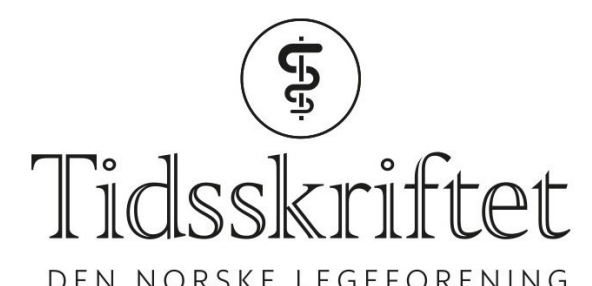

DEN NORSKE LEGEFORENING

\title{
Erythema migrans i norsk allmennpraksis
}

DOKTORAVHANDLINGER

KNUT EIRIK RINGHEIM ELIASSEN

E-post: k.e.eliassen@medisin.uio.no

Erythema migrans er vanligere i allmennpraksis enn det antallet innmeldte tilfeller skulle tilsi. Penicillin er et trygt og godt behandlingsvalg.

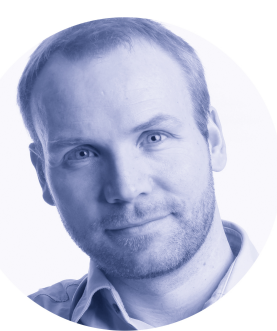

Foto:John Fredrik Kvalnes

Alvorlige former for Lyme-borreliose, som artritt eller nevroborreliose er meldepliktig i Norge. Forekomst, behandling og senfølger av erythema migrans i Norge har vært mangelfullt kartlagt.

I mitt doktorgradsprosjekt har jeg kartlagt forekomsten av legekonsultasjoner for flåttbitt og erythema migrans hos norske fastleger og legevakt, og sammenlignet behandling med penicillin, amoksicillin og doksysyklin i et randomisert, kontrollert fors $ø$ k.

Jeg fant at borreliose er mye mer vanlig i allmennpraksis enn det antallet innmeldte tilfeller skulle tilsi. Det var ingen forskjell i varighet av erythema migrans i de tre behandlingsgruppene, og kun små forskjeller i følgesymptomer og bivirkninger.

Pasientene ble fulgt i ett år. Ingen av dem utviklet alvorlig form for borreliose. Jeg undersøkte også subjektiv helseopplevelse og funksjon hos erythema migrans-pasientene. Pasientene hadde sammenlignbar symptombyrde med normalbefolkningen, og $ø$ kning i symptomer ga ikke nedsatt funksjon.

Funnene underbygger den nordiske anbefalingen om penicillin som førstevalgsbehandling ved erythema migrans. Forekomsten viser at valget av antibiotikabehandling monner i forhold til å unngå utvikling av antibiotikaresistens. Forskningen gir dessuten et bedre bilde av varighet, forløp og følgesymptomer av den mest alminnelige flåttbårne sykdommen i Norge. 


\section{Disputas}

Knut Eirik Ringheim Eliassen disputerte for ph.d.-graden ved Universitetet i Oslo 5.12.2017. Tittelen på avhandlingen er Tick-borne Lyme borreliosis - incidence, antibiotic treatment and subjective health complaints of erythema migrans patients in Norwegian general practice.

Publisert: 26. juni 2018. Tidsskr Nor Legeforen. DOI: 10.4045/tidsskr.18.0205

(C) Tidsskrift for Den norske legeforening 2020. Lastet ned fra tidsskriftet.no 